\title{
室内空気温度分布を考慮した室モデルによる室内混合損失シミュレーション SIMULATION OF MIXING ENERGY LOSS USING BLOCK MODEL CONSIDERING ROOM AIR TEMPERATURE DISTRIBUTION
}

\author{
小島昌一*, 渡辺俊行**, 龍 有二***, 赤司泰義**** \\ 西山紀光*****, 高橋淳 一****** \\ Shoichi KOJIMA, Toshiyuki WATANABE, Yuji RYU, Yasunori AKASHI, \\ Norimitsu NISHIYAMA and Jun-ichi TAKAHASHI
}

\begin{abstract}
To simulate mixing energy loss in an air-conditioned office room, it is necessary to use mathematical model considering room air temperature distribution. In this paper, we suggest new mathematical model 'six blocks model' for air-conditioning load calculation. In this mathematical model, a room is divided into six blocks. It is able to have air movement between blocks and heat distribution of air-conditioner into six blocks. After examination of the heat distribution of air-conditioner into blocks, we investigated the influence of building specification and air-conditioning system on mixing energy loss by simulation.
\end{abstract}

\section{Keywords: room air temperature distribution, mixing energy loss, six blocks model, heat distribution coefficient 室内空気温度分布，室内混合損失，6ブロックモデル，熱量配分係数}

1. はじめに

室内混合損失 ${ }^{1)}$ は、室内空気温度分布と空調機の制御が複雑に 絡んで起きる現象である2)。したがって、シミュレーションで室内 混合損失を再現するには、空気温度分布を考慮できる室モデルが必 要である。筆者らはこれまでに中間季のオフィスビルの室内熱環境 実測から、空調機の冷暖房同時運転時に発生する室内混合損失量の 推定方法を検討した ${ }^{3)}$ 。この推定方法は一つの室をぺリメータとイ ンテリアに二分割する室モデル「2ブロックモデル」で、ペリメー タ・インテリア間の空気・熱移動を考慮することにより、実測デー 夕から室内混合損失量を推定するものである。

本論文では、この 2 ブロックモデルをさらに拡張し、上中下の温 度分布を考慮できるように改良した室モデル「6ブロックモデル」を 提案し、シミュレーションによる室内混合損失の予測方法と防止策 を検討する。まず室内上下温度分布を考慮した熱負荷計算に関する 既往の研究と6 ブロックモデルの概要および空調機供給熱量の各ブ
ロックへの配分について検討した後に、6 ブロックモデルを用いた シミュレーションによる室内混合損失のケーススタディの結果につ いて報告する。

\section{2. 室内の温度分布予測に関する既往の研究}

空間を上下方向に複層に分割し、熱負荷計算時の上下温度分布を 考慮する研究が従来からいくつか試みられている。浦野・渡辺ら ${ }^{4)}$ は上下室温分布を表現するため、熱的に同一挙動、瞬時一様拡散を 仮定して室を垂直方向に 2 層から数層に分割するモデル（室温分割 モデル）を提案し、各層間の換気回数を仮定した上で室内側対流熱 伝達率が室温に与える影響を考察している。このモデルでは層間の 換気量をどう設定するかが課題である。

宮川 ${ }^{5)}$ は大空間を対象に、室を上下方向に複層に分割する室温 分割モデルを適用し、模型実験により求めた仮想換気回数を実物用 に換算して使用する方法を提案している。この方法により上下温度
$*$ 大分大学工学部建設工学科 助手・博士 (工学)

** 九州大学大学院人間環境学研究科然間システム専攻 教授. 工博

*** 九州大学大学院総合理工学研究科環境工ネルギー工学 専攻 助教授・ 工博

***** 九州大学大学院人間環境学研究科空間システム尃攻 助教授・工博

***** 久留米工業大学建築設備工学科 教授 ·博士 (工学)
Research Assoc., Dept. of Architectural Engineering, Faculty of Engineering, Oita Univ., Dr. Eng.

Prof., Dept. of Architecture, Graduate School of Human-Environment Studies, Kyushu Univ., Dr. Eng.

Assoc. Prof., Dept. of Energy and Environmental Engineering, Interdisciplinary Graduate School of Engineering Sciences, Kyushu Univ., Dr. Eng.

Assoc. Prof., Dept. of Architecture, Graduate School of Human-Environment Studies, Kyushu Univ., Dr. Eng.

Prof., Dept. of Architectural Equipment Engineering, Kurume Institute of Technology, Dr. Eng.

Taisei Corporation, M. Eng. 
分布、居住域の泠房負荷を算出することができ、実測からその有効 性を確認している。しかし、模型実験で得られた仮想換気回数は上 下方向 $2 \sim 3$ 分割の場合に限られていること、吹出し方式が限定さ れていることなどの課題が残されている。

同様に仮想室間の換気量を仮定したモデルの研究では、絵内ら ${ }^{6)}$ が大規模吹抜け空間の上下の温度積層を考虑した 1 室 3 温モデルを 提案している。このモデルは空間を上中下に 3 分割し、温度差換気 による室内の熱対流の到達域と量を気流の温度と空間の温度分布か ら算定するものである。

戸河里ら ${ }^{7)}$ は大空間の上下温度分布を簡易に予測するためのマ クロモデルを作成し、周壁の熱系と連成させた非定常計算モデルを 提示している。このマクロモデル (ブロックモデル) は、(1)壁面に 沿う下降流または上昇流を表現する「壁面流モデル、(2)空調機吹 出し気流を自由噴流として扱い、その影響を評価する「非等温噴流 モデル」、(3)空間内の上部と下部の温度差に起因する熱移動を評価 する「熱移動係数 $C_{B}$ 」の 3 つのモデルからなる。このマクロモデ ルの特徴は、空調吹出し方法や吸込み位置が上下温度分布形成に及 ぼす影響を定量的に評価できることと、空調停止中の夜間のように 自然対流によって形成される上下温度分布も予測することができる ことである。しかし、層分割数を変えると熱移動係数 $C_{B}$ も変化す ることから実測との比較によりその妥当性を検討することが課題と して残されている。

伊藤・中原ら ${ }^{8)}$ は、室上部吹出し、下部吸い込みの空気分配シ ステムを有する空調室の温風暖房時を対象に上下温度分布を簡易に 予測する計算モデルを提案している。このモデルは室内を吹き出し 温風がよく混合拡散する上部完全混合域とそれ以外の下部ピストン フロー域に分け、上下温度分布を予測するものである。実験結果と もよく一致しているが、天井吹き出し・天井吸い込み方式、床置き ファンコイルコニット方式などの他の空調システムについての有効 性は今後の検郡課題である。

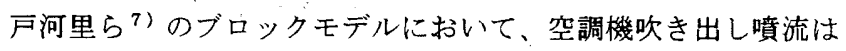
周囲の空気を噴流内部に誘引しながら空間全体に拡散するように取 り扱われている。したがって、吹き出し空気によって供給された熱 量は、ある比率で各層に配分されると考えられるので、空調機吹き 出し熱量の各層への配分が設定できれぼ吹き出し噴流の計算を省略 できる。以上のことから、石田・松本・宇田川ら ${ }^{9)}$ は、ブロック モデルにおける吹き出し噴流による空間内への熱供給モデル（非等 温噴流モデル）を熱量配分係数に圈き換えて上下温度分布を考虑し た熱負荷を求める方法を提案している。この方法は、空調機器や制 御方法が熱量配分係数に含まれるために、冷温風の風量、吹き出し 温度などの空調システム仕様が決定される以前に、上下温度分布を 考虑した計算が行えることが特徴である。住宅の暖房時の実測值と 比較した結果、適切な熱量配分係数を与えれば、熱負荷变動、室温 上下温度分布ともによく再現できると報告している。

村田・松本・宇田川ら ${ }^{10}$ は空気調和・衛生工学会熱負荷小委員 会作成のプログラムを用いて住宅の吹抜けを想定し、層分割数の熱 負荷への影響を検討している。層の分割なしから5分割まで比較し た結果、3 分割以上にしたときの負荷の差は少ない上報告している。 戸河里・武政ら ${ }^{11)}$ はアトリウムなどの大空間の熱環境を予測す るブロックモデルをそのままオフィス空間に適用した場合の問題点
について考察している。その結果、ブロックモデルは冷房時・暖房 時ともにオフィス空間の上下温度分布をある程度再現できることを 示している。ただし、下向きの温風が床に衝突する場合の再現性に 課題が残っている。

また、戸河里・武政ら ${ }^{12)}$ はブロックモデルを用いて室内混合損 失のケーススタディを行っている。このブロックモデルはペリメー タとインテリアを上下方向に複数のプロックに分割するもので、上 下方向の温度分布の予測にはブロックモデルを用い、各ブロック間 の水平方向の熱・空気の混合は温度差換気で評価している。このモ デルでは、ペリメータとインテリアの両ゾーンにまたがる吹き出し 気流の挙動を考慮しないこと、ペリメータとインテリア間の大きな 対流を取り扱わないことなど、室内空気移動の面からみて不十分な 点を有しており、実測值との比較が必要である。

\section{6 ブロックモデルの概要}

室内混合損失をシミュレーションで再現するには、室の奥行き方 向と上下方向の温度分布を考虑できる室モデルが必要であり、従来 から提案されている室モデルでは垂直方向の温度分布しか考虑しな いので限界がある。本研究では、ペリメータとインテリアをそれぞ れ上中下に分割し、1 室を 6 分割する室モデルを新たに提案する。 図ー1に6ブロックモデルにおけるブロック間の空気移動経路を、 式(1)に風量バランスを示す。このモデルでは基本的にブロックの 境界面を通して隣室ブロックのみと空気移動があるものとし、ブロ ック間の空気移動量は対象ゾーン内の空調機の吹出し風量の合計值 以下とする。また、実現象を厳密に見九ば、ブロック境界面におい てブロック空気の相互移動があるが、本論では室全体での大きな流 れ場を想定する。したがって、ブロック境界面における空気移動は

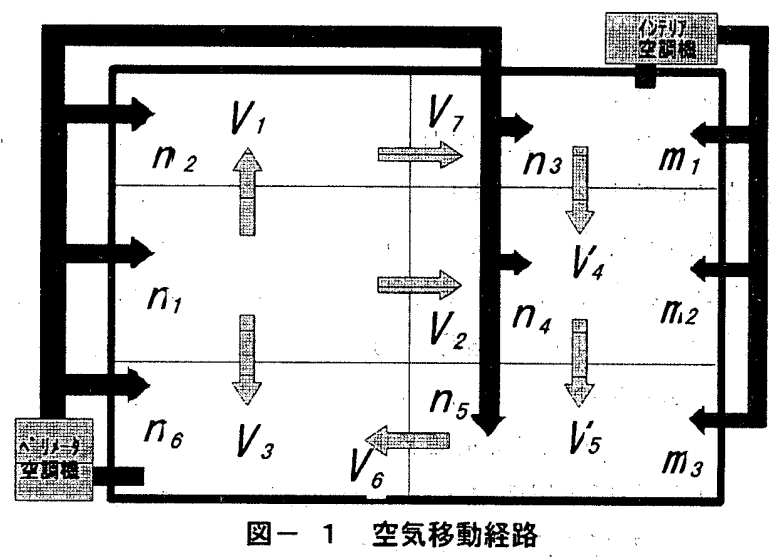

$$
\begin{aligned}
& V_{1}=a V_{P}, V_{2}=b V_{P}, V_{3}=\left(n_{1}-a-b\right) V_{P} \\
& V_{4}=\left(a+n_{2}+n_{3}\right) V_{P}+\left(m_{1}-1\right) V_{I} \\
& V_{5}=\left(a+b+n_{2}+n_{3}+n_{4}\right) V_{P}+\left(m_{1}+m_{2}-1\right) V_{I} \\
& V_{6}=\left(a+b+1-n_{1}-n_{6}\right) V_{P} \\
& V_{7}=\left(a+n_{2}\right) V_{P} \\
& -\left(V_{P}+V_{1}\right) \leqq V_{3} \sim V_{7} \leqq V_{P}+V_{I} \\
& |a| \leqq 1,|b| \leqq 1, a+b=1 \\
& V: \text { ブロック間風量, } \\
& n, m: \text { 空調機熱量配分係数 }(\Sigma n=1.0, \quad \Sigma m=1.0) \\
& V_{P}: \text { ペリメー空調機吹き出し風量, } \\
& V_{1}: \text { 仗师空調機吹き出し風量 }
\end{aligned}
$$$$
\text { 式(1) }
$$ 
空気がブロック間で相互に入れ替わる換気ではなく、一方にのみ 移動するものとした。

空調時の実際の流れ場に拉いては、空調機吹き出し空気がいくつ かのブロックを通過して離れたブロックに流入する状態が起きてい る。また、ブロックモデルではブロックに空気とともに流入した熱 は瞬時一様拡散するものとしているので、熱の流入先を適切に決定 しないと実際の流れ場と大きく異なる結果となってしまう。したが って、空調機供給熱量の配分先もブロック間の空気移動量と同時に 同定する。本研究では、空調機供給熱量の各ブロックへの配分を石 田・宇田川らの熱量配分係数 ${ }^{9)}$ にならって取り扱う。

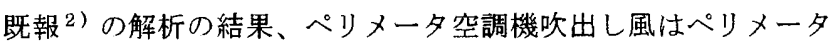
の各ブロックだけではなくインテリアの奥深くまで到達していたの で、ペリメータ空調機供給熱量は室内の全ブロックに配分される可 能性を考えた。一方、インテリア空調機の供給熱量は、インテリア 奥行きがペリメータ奥行きに対して大きいことから、直接ペリメー タの各ブロックに配分されることはないものとした。

\section{4. 空調機熱量配分係数の同定}

空調機熱量配分係数は、本来空調機吹出し空気の噴流計算を行っ て求められるが、本論で対象としているゾーンに関しては、詳細な 秋季室内熱環境実测データに基づいて空調機熱量配分係数を同定す る。対象ゾーンと空調システムを図ー2、図ー3に示す。実測時の 対象ゾーンは、ビニールシートによる間仕切りにより隣接ゾーンと の空気移動はないものとしていた。したがって、計算においても隣 接ゾーンとの空気移動はなく、ペリメータ・インテリア間の空気移 動に重点を置くものとする。秋季の室内熱環境実測の詳細について は既報2)を参照されたい。

各ブロック境界面での空気移動量および移動方向は、図ー 1 と式 (1)に示した条件により、各ブロックごとに空気温度の計算值と実 測值の差を求め、その二乗和が最小になるように計算により決定す る。計算方法は内部発熱量、空調機除去（供給）熱量、壁体各部位 の表面温度の実測值を基に室温を計算するもので、空面からの透過 日射および室内表面閒の短波・長波域の多重反射・吸収の影響は表 面温度の実測值に含まれるものとした。各ブロックの空気の熱収支 は壁体表面との対流熱伝達、内部発熱、空調機除去（供給）熱量お よび隣接するブロックから流入する熱量が関与するものとした。

ブロックの分割方法については、図ー4に示す空調時の上下温度 分布に执いて、ペリメータ奥行き $4 \mathrm{~m}$ から $8 \mathrm{~m}$ の間にインテリアと ペリメータの熱的緩衝空間が見られることから、その中間点の $6 \mathrm{~m}$ の位置でペリメータとインテリアを分割した。また、高さ方向に関 しては、図ー3に示すように垂れ壁、空、腰壁の高さに対応して上、



計算対象期間は実測期間中の 1993 年 10 月 25 26 日の 2 日間で ある。計算時間間隔は 10 分とした。照明機器などの内部発熱につ いては、放射成分は天井・床などの表面温度の実測值に含まれると し、対流成分のみ空気に入るものとした。また、非空調時は2 2 ブロ ックによる計算とし、ペリメータとインテリアの空気移動は、ペリ メータ容積基準で換気回数 20 回 $/ \mathrm{h}$ とした。

図ー5に同定したペリメータとインテリアの空調機熱量配分係数 を暖房、冷房、送風の 3 つの空調機運転状況別に示す。図中に示し

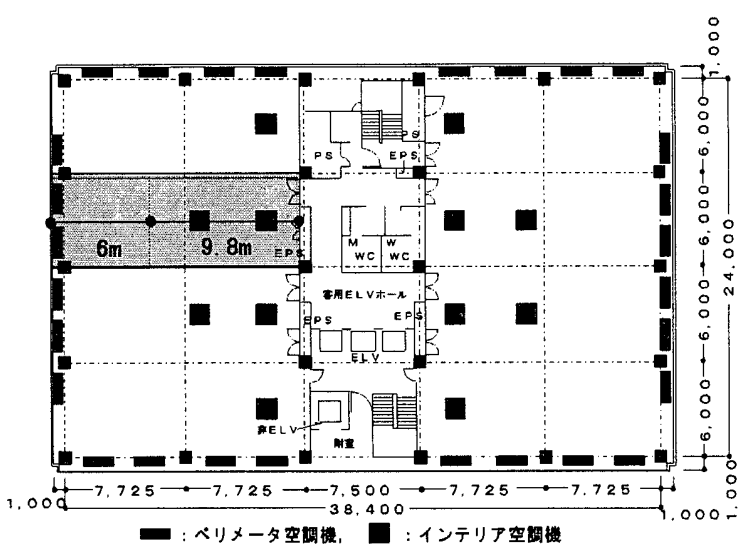

图一2 対象ソーン (単位 : mm)



図一 3 空調システム（単位 $: \mathrm{mm}$ )

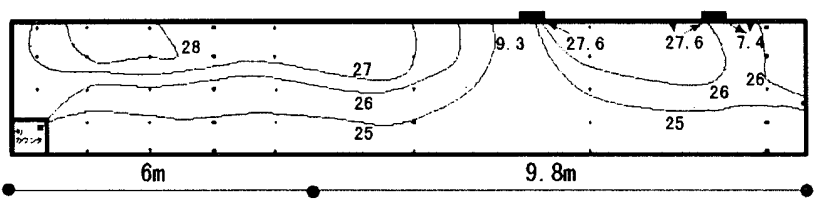

図一 4 空気温度分布 (10月 27 日 $8: 20$, 単位 : ${ }^{\circ} \mathrm{C}$ )



(a)ペリメータ空調機の熱量配分係数

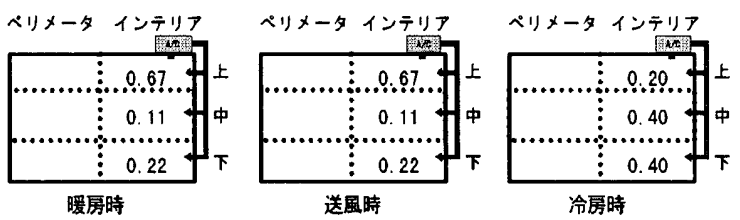

(b)インテリア空調機の熱量配分係数

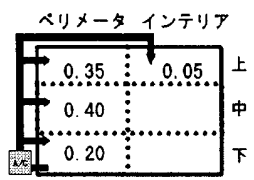

(c)ペリメータ空調機空調立ち上がり時（暖房）の熱量配分係数

図一 5 空調機熱量配分係数

た空調機熱量配分係数は同定で得られた各時刻毎の空調機熱量配分 係数の平均值である。ただし、インテリア暖房時の空調機熱量配分 係数については、害測時にインテリア暖房がなかったのでインテリ ア送風時の熱量配分係数と同じ值とした。また、ペリメータ空調機 の立ち上がり時 (暖房) の空調機熱量配分係数は他の暖房時の值と 大きく異なったので、ペリメータ空調機の立上がり時が暖房の場合 は、ペリメータ空調立ち上がり用の熱量配分俰数を用いることにし た。なお、各空調機の熱量配分係数の合計値は 1.0 である。 
ペリメータ空調機が暖房時と冷房時では各ブロックへの熱量配分 係数が全く異なるのがわかる。ペリメータ空調機が暖房運転の場合、 空調機吹き出し温風はペリメータよりもむしろインテリアの上、中 ブロックに多く配分されている。また、ペリメータ空調機が冷房運 転の場合、空調機吹き出し泠風が最も多く流入するのはペリメータ およびインテリアの下ブロックであった。

インテリア空調機については、送風時は大半がインテリア上ブロ ックに配分され、インテリア空調機が冷房運転の場合は大部分の吹 出し冷風がインテリア中、下ブロックに配分される。

\section{5. シミュレーションの概要}

5.1 シミュレーション方法

シミュレーション項目を表ー1 に示す。本シミュレーションでは 建物仕様と空調設定条件の二つが室内混合損失の発生に与える影響 を検討した。建物仕様の検討については、外壁壁面方位と外壁断熱 性能の影響を検討した。空調設定条件の検討については、空調設定 温度、空気温度センサ位置の影響を検討した。本シミュレーション の計算方法は、同定した空調機熱量配分係数を用いて、標準気象デ 一タ、建物仕様、空調機設定条件から各ブロックの空気温度の変動 と空調機除去熱量を求めるもので、壁体および室内空気の熱収支は 逐次状態遷移の概念 ${ }^{3}$ 3) に基づいて計算した。また、空調時は 6 ブ ロックで計算するが、非空調時は上下温度分布を考虑しない 2 ブロ

表一 1 シミュレーション項目

\begin{tabular}{|c|c|}
\hline 外壁壁面方位 & 東西南北の 4 方位 \\
\hline 外壁断熱性能 & 基準壁体, 高断熱壁体 \\
\hline 空調設定温度 & 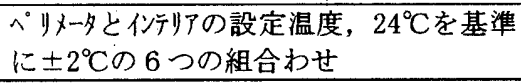 \\
\hline 空気温度センサ位置 & $\begin{array}{l}\text { ベリメータ, 价师の上中下の } 3 \text { ブロ㚈つ } \\
\text { いて9つの組合わせ }\end{array}$ \\
\hline
\end{tabular}

\section{表-2 基準計算条件}

\begin{tabular}{ll}
\hline 計算期間 & $\begin{array}{l}\text { 外壁壁面方位別の計算では } 2 \text { 月の } 1 \text { ヶ } \\
\text { 月間。その他の計算では } 2 \text { 月 } 13,14 \text { 日 } \\
\text { の } 2 \text { 日間 (助走計算は } 10 \text { 日間) }\end{array}$ \\
\hline 計算時間間隔 & 10 分 \\
\hline 気象データ & 標準気象データ(福岡, 2 月) \\
\hline 空調日・時間帯 & 月〜金曜日 $8 \sim 18$ 時 \\
\hline 内部発熱 (対流成分) & 上 $7.5 \mathrm{~W} / \mathrm{m}^{2}$, 中 $10.6 \mathrm{~W} / \mathrm{m}^{2}$, \\
& 下 $4.6 \mathrm{~W} / \mathrm{m}^{2}$, 月〜金曜日 $9 \sim 18$ 時
\end{tabular}

内部発熱（放射成分）天井: $10.2 \mathrm{~W} / \mathrm{m}^{2}$, 床 $8.8 \mathrm{~W} / \mathrm{m}^{2}$ 月～金曜日 $9 \sim 18$ 時

\begin{tabular}{|c|c|}
\hline $\begin{array}{l}\text { 非空調時のペリメータ. } \\
\text { 价少間換気回数 }\end{array}$ & 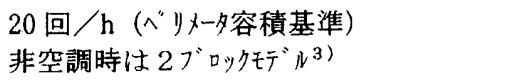 \\
\hline 空調設定温度 & 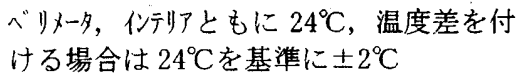 \\
\hline 空気温度ゼ位置 & ベリメータ：下ブロック，代师ア：中ブロック \\
\hline 空調機吹出し風量 & ベリメータ $1330 \mathrm{~m}^{3} / \mathrm{h}$, 仗归ア $800 \mathrm{~m}^{3} / \mathrm{h}$ \\
\hline 外気導入量 & $\begin{array}{l}\text { ペリメータ空調機から } 300 \mathrm{~m}^{3} / \mathrm{h} \\
\text { 月〜金曜日 } 9 \sim 18 \text { 時 }\end{array}$ \\
\hline
\end{tabular}

\begin{tabular}{l} 
外壁壁体構成*，腰壁 : 外壁 1 , 垂壁 : 外壁 2 \\
\hline *外壁番号は図ー7 を参照のこと
\end{tabular}

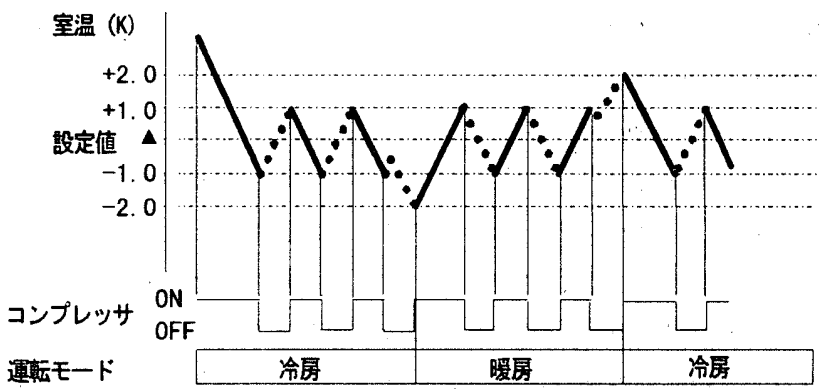

図-6 空調機運転動作

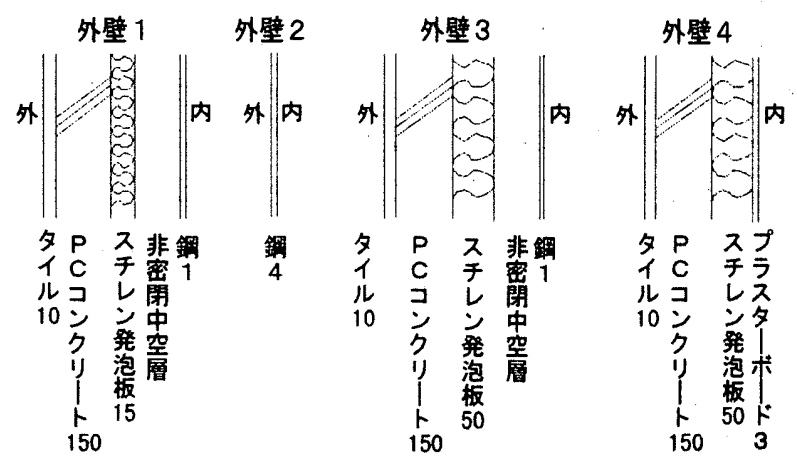

图-7 外壁壁体構成（単位：mm）

$$
\begin{aligned}
& Q_{i}=V_{i} C \rho\left(T_{i}-T_{i j}\right) \\
& M L=\Sigma\left|Q_{i}\right|
\end{aligned}
$$

式(2)

$Q_{i}$ : 移動熱量, $V_{i}:$ ブ㕫容積, $M L$ : 全室内混合損失量,

$T_{i} \quad:$ ブロ叻温度(空気移動あり),

$T_{i, 0}:$ ブ咖温度(空気移動なし),

$C$ : 空気の比熱, $\rho:$ 空気の比重量

i : ブ唯番号

ックモデル3) で計算した。本シミュレーションにおける空調機の 制御は、图ー6に示すように実測時の空調機の運転動作と同じ ON/OFF 制御とした。

本シミュレーションでのブロック間の空気移動は、ペリメータと インテリアでそれぞれ上下温度勾配が付くことと、ペリメータとイ ンテリア間の温度差が最小になるという2つの条件を与えて風量を 同定しながら計算した。

\section{2 計算条件}

基準計算条件を表一 2 に示す。計算期間については、外壁壁面方 位別の計算では 2 月の 1 ヶ月間とし、その他の計算では 2 月 13,14 日の 2 日間とした。各計算の助走計算は 10 日閒とした。計算対象 ゾーンは、空調機熱量配分係数を同定したソーンと同一である（図 一2)。ただし、外壁壁面方位の検討に際して外壁壁面方位を变え る場合は、フロアに占める対象ゾーンの位置はそのままで、建物自 体の方位が変わるものとした。内部発熱については表一2に示すよ うに対流成分と放射成分に分けて計算した。また、本シミュレーシ ヨンでは内部発熱時間帯にペリメータ空調機を通して外気を導入す るものとした。

外壁壁体構成は図ー7に示す通りである。室内混合損失量の推定 は式(2)に示すように、他ブロックへの熱移動がない場合の空気温 度と熱移動がある場合の空気温度の差加ら移動熱量を求め、その絶 
対値の和を全室内混合損失量とした。ただし、室内混合損失量とし て扱うのは冷暖房同時発生時のみとした。なお、熱移動がない場合 の空調機供給熱量の各ブロックへの配分は、ペリメータ空調機はぺ リメータの各ブロックだけに、インテリア空調機はインテリアの各 ブロックだけに容積比率に応じて配分されるものとした。

\section{6. シミュレーション結果}

\section{1 外壁壁面方位の影響}

外壁壁面方位別に室内混合損失発生状況をシミュレーションによ り検討した。空気温度センサ位置は表一 2 の基淮計算条件と同じく ペリメータは下ブロック、インテリアは中ブロックである。計算対 象期閒のうち、2月 $13 、 14$ 日の外気温度、水平面全天日射量を図 -8に、外壁壁面方位別の室内混合損失量の日積算值および月積算 值と混合損失率を表一 3 に例示する。なお、混合損失率とは空調機 処理熱量に占める室内混合損失量の割合とする。

外気温が低く、日射量も少ない 2 月 14 日はペリメータで暖房運 転になりやすい。全ての方位において、空調立ち上がり時は蓄熱負 荷の影響によりペリメータ、インテリアともに空調機は暖房運転と なった。空調機処理熱量が最も多いのは外壁壁面方位が北向きの場 合で、最も少ないのは南向きの場合である。

2 月の混合損失率は約 26〜37\%となった。また、4 方位の中で 最も室内混合損失の発生量が多いのは外壁壁面方位が北向きの場合 であり、室内混合損失量、混合損失率ともに他の方位より大きい。 これは、北に面したペリメータにおいて暖房となる時間が長いこと により、冷房状態のインテリアとの間での室内混合損失も多くなっ たものと考えられる。

外壁壁面方位が東向きの場合、一日を通して冷暖房併存状態とな りやすく室内混合損失量も多いが、特に空調立ち上がりから午前 10 時頃までと外壁面への日射が少なくなる午後 15 時以降はペリメー タで暖房となることが多いため、冷房状態のインテリアとの間で室 内混合損失が発生する。

外壁壁面方位が西向きの場合、午前中はペリメータが暖房とな ることにより冷房状態のインテリアとの間で室内混合損失が発生す るが、午後から日射の影響によりペリメータ空調機が送風運転とな るため室内混合損失は解消されることが多い。また、日射量が少な い日でも、外気温が高ければペリメータで送風となるので室内混合 損失注発生しにくい。

外壁壁面方位が南向きの場合、日射の影響によりペリメータの暖 房負荷が少ないので、他の方位に比べて室内混合損失量も少ない。

\section{2 外壁断熱性能の影響}

表ー4に壁体の組み合わせを示す。基淮壁体と、基準壁体より断



図一 8 外界気象 (外気温度, 水平面全天日射量)

\begin{tabular}{|c|c|c|c|c|}
\hline 方位 & 計算月日 & 混合損失量* & 空哃楼処理熱量* & 混合損失率 \\
\hline \multirow[t]{3}{*}{ 東 } & 2 月 13 日 & 131 & 306 & $43 \%$ \\
\hline & 2 月 14 日 & 125 & 313 & $40 \%$ \\
\hline & 2 月積算 & 1385 & 3892 & $36 \%$ \\
\hline \multirow[t]{3}{*}{ 西 } & 2 月 13 日 & 101 & 269 & $38 \%$ \\
\hline & 2 月 14 日 & 118 & 296 & $40 \%$ \\
\hline & 2 月積算 & 1292 & 3810 & $34 \%$ \\
\hline \multirow[t]{3}{*}{ 南 } & 2 月 13 日 & 51 & 174 & $29 \%$ \\
\hline & 2 月 14 日 & 88 & 238 & $37 \%$ \\
\hline & 2 月積算 & 776 & 3006 & $26 \%$ \\
\hline \multirow[t]{3}{*}{ 北 } & 2 月 13 日 & 135 & 330 & $41 \%$ \\
\hline & 2 月 14 日 & 120 & 313 & $38 \%$ \\
\hline & 2 月積算 & 1589 & 4338 & $37 \%$ \\
\hline
\end{tabular}

* 熱量単位よMJ/day またはMJ/month
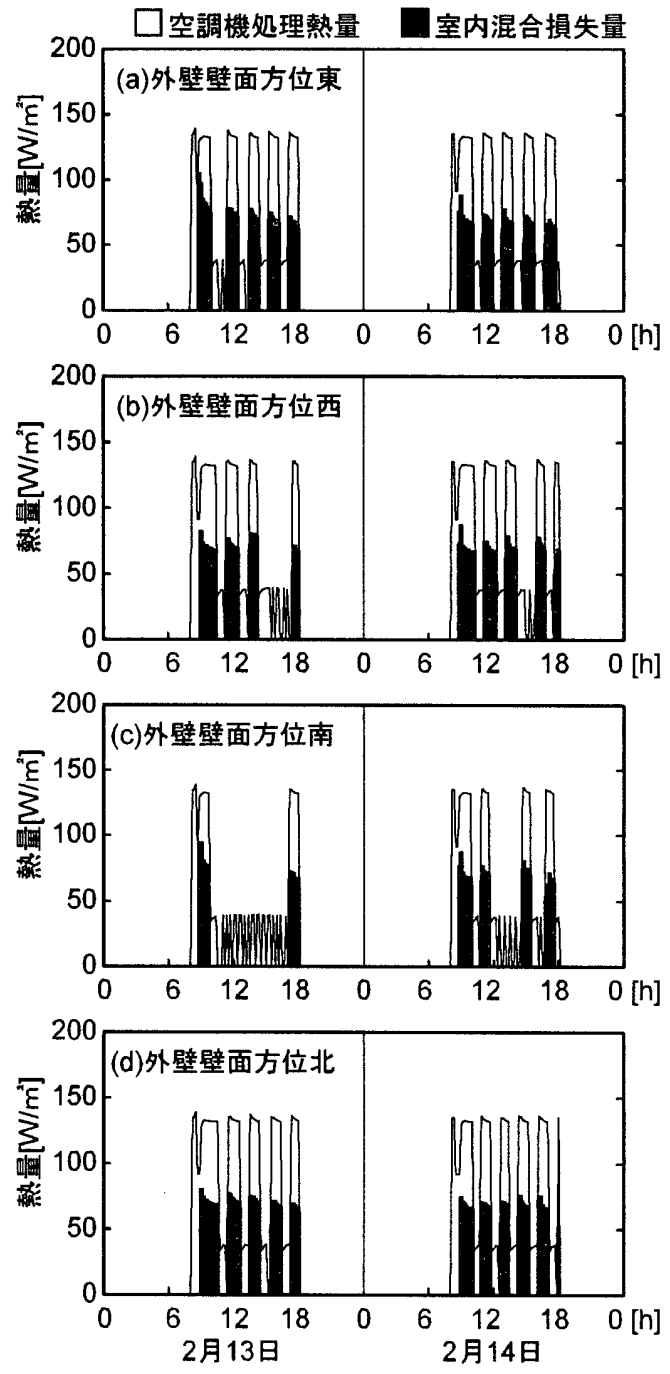

\section{図-9 空調機処理熱量と室内混合損失量}

熱性能が高い高断熱壁体について検討した。高断熱壁体で使用する ペアガラスについては、ガラス間の空気層の熱収支および放射は考 虑せず、ペアガラス全体の熱貫流率と日射透過率を与えて簡易的に 計算した。計算対象ゾーンは図ー2に示す通りで、計算期間は 2 月 13、14日の 2 日間とした。また、空気温度センサ位置、空調設定 


\section{表 -4 壁体の組合わせ}

\begin{tabular}{|c|c|c|c|c|}
\hline 断熱性能 & 腰壁* & 垂壁* & \multicolumn{2}{|c|}{ 窒ガラス } \\
\hline 高 & 外壁 3 & 外壁 4 & \multicolumn{2}{|c|}{ ペアがラス** $26 \mathrm{~mm}$} \\
\hline 基準 & 外壁 1 & 外壁 2 & \multicolumn{2}{|c|}{ 吸熱ガラス $10 \mathrm{~mm}$} \\
\hline \multicolumn{5}{|c|}{$\begin{array}{l}* \text { 外壁番号は图ー6を参照のこと } \\
* * \text { ヘヘアガラスの構成は、吸熱 } 10 \mathrm{~mm}+\text { 空気層 } 6 \mathrm{~mm}+\text { 透明 } 10 \mathrm{~mm}\end{array}$} \\
\hline 表-5 断 & \multicolumn{4}{|c|}{ 断熱性能別室内混合損失量, 混合損失率 } \\
\hline ケース & 混合損失量* & 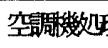 & & 混合損失率 \\
\hline \multicolumn{5}{|l|}{2 月 13 日 } \\
\hline 高 & 52 & 175 & & $29 \%$ \\
\hline 基準 & 105 & 282 & & $37 \%$ \\
\hline \multicolumn{5}{|l|}{2 月 14 日 } \\
\hline 高 & 81 & 204 & & $40 \%$ \\
\hline 基淮 & 122 & 306 & & $40 \%$ \\
\hline
\end{tabular}

*熱量単位はMJ//day

温度は表ー2の基準計算条件に示す通りである。

表一 5 に室内混合損失量の日積算値と混合損失率を示す。高断熱 壁体の方が基淮壁体より室内混合損失量が少ないことから、断熱性 能が高いほど暖房負荷が低减され、空調機処理熱量、室内混合損失 量ともに減少するものと考えられる。

2 月 13 日と 14 日では昼閒の外気温に大差はないが、2月 14 日 は日射量が少ないため 2 月 13 日よりペリメータの暖房負荷が大き くなり、室内混合損失量も增えたものと考えられる。

\section{3 空調設定温度の影響}

計算対象ゾーン、建物仕様、空気温度センサ位置は基淮計算条件 の通りである。表一 6 に 2 月 14 日の室内混合損失量の日積算値と 混合損失率を例示する。ペリメータ設定温度をインテリアより低く したケース 1 とケース 3 は室内混合損失量が少なく、ペリメータ設 定温度がインテリアより高いケース 2 が最も室内混合損失量が多い 結果となった。ケース 1 と 2 の空気温度と空調機処理熱量および室 内混合損失量の経時変化を図一10に示寸。

ケース 1 では空調立ち上がり時以外は送風運転であり、空気温度 も送風運転による成り行き温度となった。また、ケース 1 の方がケ 一ス 3 より室内混合損失量が少ないことから、ペリメータ空調機が 冷房運転にならない程度にペリメータ設定温度が低いほど室内混合 損失量は堿少するであろう。逆に、ケース $2 、 4$ の結果から、ペリ メー夕設定温度が高いほど、空調機処理熱量も増え、室内混合損失 量も増えると考えられる。

図ー11にケース 1 とケース 2 にPMV を示す。ここで示す PMV は、ペリメータ、インテリアともに中ブロックの空気温度を基準と し、着衣量 $1 \mathrm{clo}$ 、代謝量 $1.2 \mathrm{met}$ 、相対湿度 $60 \%$ 、気流速度 $0.15 \mathrm{~m} / \mathrm{s}$ で計算したものである。ケース 1 のペリメータの PMVは 0〜0.4、 インテリアの PMV は 0.3〜0.7 で推移している。したがって、空

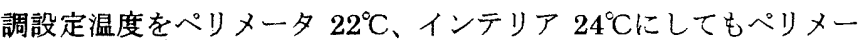
夕の熱的快適性が大きく損なわれることはないと考えられる。

\section{4 空気温度センサ位置の影響}

空気温度センサの位置は、ペリメータ、インテリアともに上中下 の3 点の組み合わせで計 9 ケースについて検討した。計算対象ジー ン、建物仕様、空調設定温度は前節までの基準の仕様とし、空気温

\begin{tabular}{|c|c|c|c|c|c|}
\hline$r-x$ & $\mathrm{P}$ 設定 & I設定 & 混合損失量* & 空毁周機边理熱量* & 混合損失率 \\
\hline 1 & $22^{\circ} \mathrm{C}$ & $24^{\circ} \mathrm{C}$ & 0 & 31 & $0 \%$ \\
\hline 2 & $26^{\circ} \mathrm{C}$ & $24^{\circ} \mathrm{C}$ & 154 & 375 & $41 \%$ \\
\hline 3 & $24^{\circ} \mathrm{C}$ & $26^{\circ} \mathrm{C}$ & 16 & 82 & $20 \%$ \\
\hline 4 & $24^{\circ} \mathrm{C}$ & $22^{\circ} \mathrm{C}$ & 146 & 338 & $43 \%$ \\
\hline
\end{tabular}

*熱量単位よMJ/day
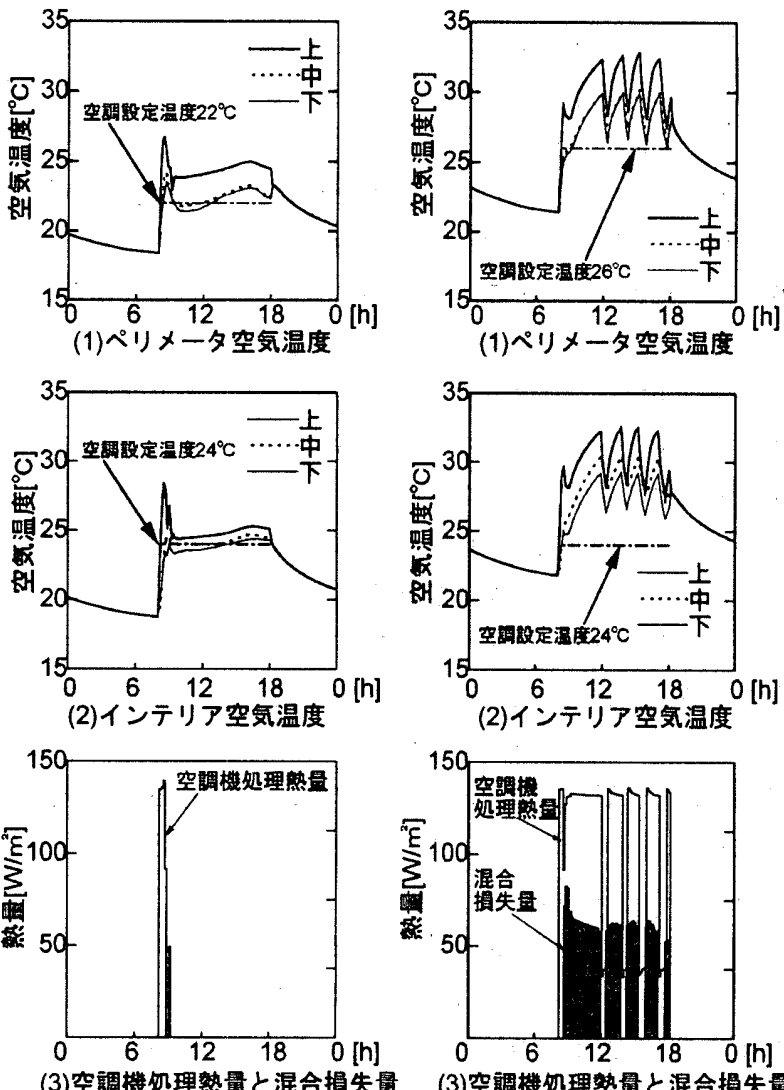

(3)空調機処理熱量と湿合賣失

(a)ケース 1 (ペリメータ $22^{\circ} \mathrm{C}$

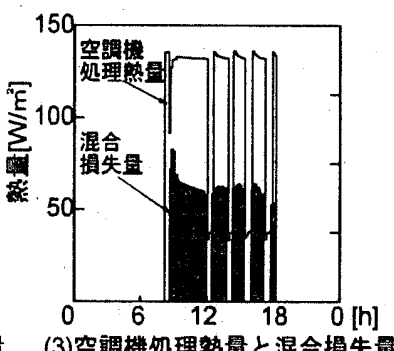

(3)空胭機処理烝貫之混合损失量 (b) インテリア $24^{\circ} \mathrm{C}$ 䖉定

図-10 空気温度と室内湿合損失量の経時変化

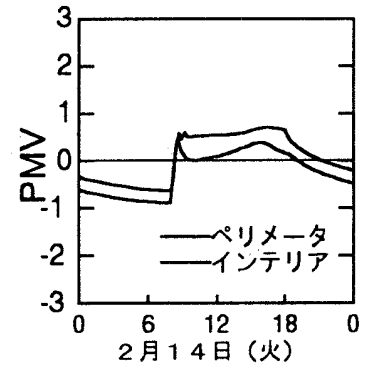

(a)ケース 1 (ペリメータ $22^{\circ} \mathrm{C}$ インテリア $24^{\circ} \mathrm{C}$ 設定)

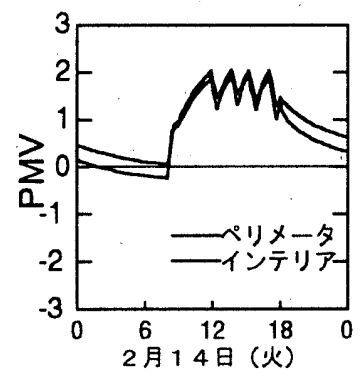

(b)ケース2(ペリメータ $26^{\circ} \mathrm{C}$ インテリア $24^{\circ} \mathrm{C}$ 設定)
图一11 空調設定温度別PMV経時变化

度センサの位置のみを変えた。

表一 7 に 2 月 14 日の室内混合損失量の日積算值と混合損失率を 例示する。最も室内混合損失量が少なかったのは、ペリメータの空 気温度センサが中ブロック、インテリアの空気温度センサが下ブロ ックのケース 6 である。ペリメータの空気温度センサが中ブロック または下ブロックにある場合、ペリメータ空謂機は暖房運転あるい は送風運転になりやすいことから、インテリアの空気温度センサは 
表 -7 空調機也州位置別室内混合損失量, 混合損失率

\begin{tabular}{|c|c|c|c|c|c|}
\hline$\overline{r-x}$ & $\mathrm{P}$ 位置 & I位置 & 混合損失量* & 空啁拣数起理熱量* & 混合損失率 \\
\hline 1 & 上 & 上 & 11 & 51 & $22 \%$ \\
\hline 2 & & 中 & 243 & 256 & $95 \%$ \\
\hline 3 & & 下 & 191 & 231 & $83 \%$ \\
\hline 4 & 中 & 上 & 134 & 306 & $44 \%$ \\
\hline 5 & & 中 & 42 & 188 & $22 \%$ \\
\hline 6 & & 下 & 3 & 99 & $3 \%$ \\
\hline 7 & 下 & 上 & 163 & 347 & $47 \%$ \\
\hline 8 & & 中 & 122 & 306 & $40 \%$ \\
\hline 9 & & 下 & 78 & 246 & $32 \%$ \\
\hline
\end{tabular}

*熱量単位はMJ/day

ペリメータ空調機の温風の影響を受けにくい下ブロックにある場合 が最も室内混合損失が少なくなった。

図-12にケース6（ペリメータ中、インテリア下で制御）とケ ース8 (ペリメータ下、インテリア中で制御) の PMV を示す。ケ ース 8 のペリメータの PMV は 0.4〜1.2、インテリアの PMVは 0.6 〜 1.3 で推移している。室内混合損失量の最も少なかったケース 6 では、ペリメータの PMV は 0.3〜0.7、インテリアの PMV は 0.6 〜0.9 で推移している。したがって、ケース6のようにペリメータ 中ブロック、インテリア下ブロックに空気温度センサを設置すれば、 基準となるケース 8 より室内混合損失を防止できるだけでなく、 熱的快適性も損なわれないであろう。

\section{7. おわりに}

室内空気温度分布を考虑できる室モデル「6ブロックモデル」の概 要と6ブロックモデルにおける空調機供給熱量の各ブロックへの配 分について検討した。また、同定した空調機熱量配分係数を用いて 室内混合損失に関するシミュレーションを行った。以下に本論文で 得られた知見を列記する。

(1) 本論文で想定した建物および空調システムでは、福岡におけ る2月の混合損失率は約 26 37\%であった。 4 方位の中で最 も室内混合損失が多く発生したのは外壁壁面方位が北向きの 場合で、最も少なかったのは南向きの場合であった。

（2）外壁の断熱化を図ることによりペリメータ暖房負荷を軽减す れば室内混合損失は低減される。

（3）ペリメータ空調温度をインテリアより低く設定することによ り室内混合損失を防止できる。また、この場合の室内熱環境 の悪化は見られず、むしろ室内混合損失が発生しないことに より良好な熱環境が得られる。

（4）本論文で想定した空調システムでは、ペリメータの空気温度 センサは部屋の高さ方向の中閒点、インテリアの空気温度セ ンサは部屋の下部に設置する組み合わせが最も室内混合損失 防止効果があるだけでなく、上記 (3) と同様に室内熱環境も良 好であった。

（5）空調機設定条件の改良による室内混合損失防止効果を確認で きたことから、空気温度センサ取り付け位置を含めた空調機 制御方法の改良は今後の室内混合損失防止策として重要な課 題と考えられる。

(6) 本論文のシミュレーションで用いた空調機熱量配分係数は、ペ リメータ空調機は床置き型、インテリア空調機は天井カセット

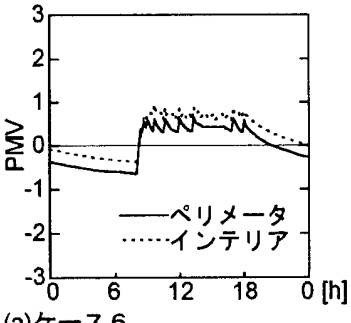

(a)ケーズースータ中, インテリア下 に設置)



(b)ケース ペメータ下, インテリア中

\section{图一12 空調機センサ位置別PMV 経時変化}

型で、空調機吹出し風速も一定の場合の值である。したがっ て、今後他の空調システム、室形態における室内湜合損失につ いて検討する場合、その空調システムと室形態に応じた空調機 熱量配分係数が必要である。

謝辞

本研究の一部は平成 8 年度文部省科学研究費補助金によるもの である。ここに記して謝意を表す。

\section{参考文献}

1）中原信生，梶原豊久，伊藤尚寛：空気調和における室内混合損失の 防止に関する研究, 第 $1 ， 2$ 報, 空気調和・衛生工学会論文集, №.33,

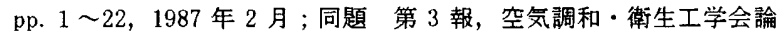
文集, No.41, pp. 51 60, 1989 年 10 月

2）小島昌一, 渡辺俊行, 他:オフィスビル空調における室内混合損失 の影響，日本建筑学会計画系論文集，第 473 号, pp. $25 \sim 34,1995$ 年 7 月

3）小島昌一, 渡辺俊行, 他： 2 室モデルによる室内混合損失量の推定, 日本建築学会中国·九州支部研究報告，第 10 号，pp. 389 392，1996 年 3 月

4）浦野良美, 渡边俊行：室温変動における室内側熟伝達率の影響, 日 本建築学会大会学術講演梗概集，pp. 303 304，1973 年 10 月

5 ）宮川保之：大空間の上下室温分布算定に関する実験的研究，日本建 築学会論文報告集，第 286 号，pp. 75 82，1979 年 12 月

6) 絵内正道, 荒谷 登, 他 : 温度積層空問を上中下の 3 仮想室に分割 した非定常熟解析手法と大規模吹技け空間一の適用結果，日本建築 学会計画系論文報告集，第 419 号, pp. 21 29, 1991 年 1 月

7 ） 戸河里 敏, 他 : 大空間における上下温度分布予測モデル 大空間 の空調・熱環境計画手法の研究 その 1 ，日本建築学会計画系論文 報告集，第 427 号，pp. 9 19，1991 年 9 月; 同題 その 2, 第 435 号, pp. 11 21，1992 年 5 月; 同題 その 3 ，第 455 号, pp. 23〜30, 1994 年 1 月

8）伊藤尚寛，中原信生：温風暖房空間の上下温度分布の簡易計算モデ 儿空調空間の熱的特性に関する研究 第 2 報, 日本建筑学会計画 系論文報告集，第 398 号，pp. 59 67，1989 年 4 月

9) 石田建一, 松本 雄, 宇田川光弘：上下温度分布を考慮した熱負荷 計算 その 1 熱量配分倸数を用いた計算法, 空気調和・衛生工学 会学術講演会請演論文集, pp. 77〜 80, 1992 年 7 月; 同題 その 2 住 宅の塞测値を用いた検証, 空気調和・衛生工学会学術講演会䛾演論 文集, pp. 81 84，1992 年 7 月

10）村田太市，松本 雄，宇田川光弘：垂直温度分布を考虑した熱負荷 計算における層分割数の影響, 日本建築学会大会学術講演梗概集, pp. 1403〜1404, 1993 年 9 月

11 ) 戸河里 敏, 武政祐一: オフィス空間の空調・熟環境計画手法の研 究その1 空調空気鉛直吹出時の上下温度分布予測, pp. 637 $638 ， 1992$ 年 8 月; 同題その 2 天井アネモ吹出時の室内熱環境 計算結果, 日本建築学会大会学術講演梗概集, pp. 639 640, 1992 年 8 月

12) 戸河里 敏, 武政祐一：オフィス空間の空調・熱噮境計画手法の研 究その 7 ベリメータとインテリアの熱・空気の混合評価モデ ル, pp. 738 739，1995 年 8 月; 同題 その8 ペリメータとイン テリアの熱混合問題のケーススタディと対策, 日本建筑学会大会学 術講演梗概集, pp. 739 740，1995 年 8月

13 ) 渡边俊行: 室温変動系の理論桡成と動的举動に関す万研究, 学位論 文 (九州大学)，1982 年 6 月

（1997年6月23日原稍受理，1998年 2 月 2 日採用決定） 